\title{
Grass Repellency to the Red Imported Fire Ant
}

\author{
Troy Sternberg, ${ }^{1}$ Gad Perry, ${ }^{2}$ and Carlton Britton ${ }^{3}$ \\ Authors are ${ }^{1}$ Fulbright Scholar and former Graduate Research Assistant, ${ }^{2}$ Assistant Professor, and \\ ${ }^{3}$ Professor, Department of Range, Wildife and Fisheries, Texas Tech University, Lubbock, TX 79409.
}

\begin{abstract}
The red imported fire ant (Solenopsis invicta Buren) is an invasive pest that causes ecological disturbance and economic damage to habitats worldwide. Since its introduction to the United States 75 years ago, the ant has spread across the southeast through Texas into California and causes over $\$ 6.5$ billion in damages. Conventional control techniques have not proven effective or long-lasting, leading to a search for alternative methods. We examined the ability of WW-B.Dahl Old World bluestem (Bothriochloa bladhii [Retz] S.T. Blake), increasingly used in pastures, to limit or reduce ant infestations. Pastures planted with WW-B.Dahl had about one-third the fire ant mounds found in adjacent pastures of native grass or coastal bermuda (Cynodon dactylon [L.] Pers) grass, and the difference is statistically significant $(P=0.0006)$. No difference was found in the number of ants collected in bait cups or in mound vitality ratings, suggesting that more than one measure of ant infestation is needed to accurately assess ant populations. A reduction in fire ant mounds can improve the efficiency of haying operations and reduce wildlife impacts, suggesting broad uses for WW-B.Dahl in ant-infested areas.
\end{abstract}

\section{Resumen}

Las hormigas coloradas o de fuego (Solenopsis invicta Buren) son una plaga invasora que causa serios disturbios ecológicos y considerables pérdidas económicas en diferentes regiones del mundo. Desde su introducción a los Estados Unidos hace más de 75 años, estas hormigas han invadido el sureste del país, desde Texas hasta California, ocasionando daños por más de 650 millones de dólares. Por otro lado, las técnicas convencionales utilizadas para su control carecen de efectividad, o bien, este ha sido de poca duración, por lo que se continúa buscando nuevas alternativas para su erradicación. En este sentido, se evaluó la efectividad del pasto WW-B.Dahl cuyo uso se ha incrementado para delimitar o reducir la infestación de estas hormigas. Así, en potreros con WW-B.Dahl se encontró una menor cantidad de montículos que en potreros adyacentes de pastizal nativo o pasto bermuda. No se encontró diferencia en la cantidad de hormigas recogidas en vasos recolectores o en los índices de vitalidad de los montículos. Esto sugiere que es necesario tomar más de una medida de la infestación de hormigas para evaluar con mayor precisión su población. Una reducción en el número de montículos podría mejorar la eficiencia en la producción de heno, reducir efectos negativos en la fauna silvestre y ampliar la utilización del WW-B.Dahl en áreas infestadas por hormigas coloradas.

Key Words: WW-B.Dahl, improved pasture grass, ant repellency, Solenopsis invicta, Bothriochloa bladhii

\section{INTRODUCTION}

The red imported fire ant (Hymenoptera: Formicidae, Solenopsis invicta, Buren; RIFA), a noxious exotic pest, entered the United States in 1929 from Brazil (Vinson 1997). Numerous control efforts, including quarantines and chemical eradication programs, have been unsuccessful. Lacking natural enemies, RIFA infests over 120 million ha in the southeastern United States; is now established in California, the Caribbean, and Australia (Morrison 2004); and causes billions of dollars in damages. For example, RIFA-related damages and expenditures in Texas are estimated to exceed $\$ 1.2$ billion per year (Lard et al. 2001).

Past failures to control this pest emphasize the need for creative approaches to managing RIFA, and several such

Research was supported by the Texas Imported Fire Ant Research and Management Project and Texas Tech University.

The first author is currently a graduate student at St. Cross College, St. Giles, Oxford OX1 3LZ, UK.

Correspondence: Gad Perry, Department of Range, Wildlife and Fisheries Management, Box 42125, Texas Tech University, Lubbock, TX 79409-2125. Email: Gad.Perry@ttu.edu

Manuscript received 11 September 2005; manuscript accepted 12 March 2006. projects are currently in progress. One potential method of controlling RIFA is to identify habitat characteristics that are antagonistic, repellent, or resistant to RIFA infiltration. Recently, Britton et al. (unpublished data, 2002) observed that a small number of pastures planted with WW-B.Dahl (Bothriochloa bladhii [Retz] S.T. Blake) grass showed lower mound population densities than adjacent fields. WW-B.Dahl is a recently released Old World bluestem, which is highly productive and favored by cattle (Villalobos et al. 2003). If the observation of Britton et al. (unpublished data, 2002) is correct, this grass offers an economically attractive method of reducing ant impacts, improving production, and improving the habitat for wildlife compared with other pasture grasses currently in broad use. However, Britton et al. (unpublished data, 2002) only surveyed a small number of sites, and their initial observations are hard to generalize. We, therefore, chose to greatly expand the scope of their work using multiple sites throughout the state of Texas and focusing on WW-B.Dahl Old World bluestem. Our objective was to determine whether RIFA population densities differ among pasture grasses, and we hypothesized that ant densities would be lower in pastures with WW-B.Dahl grass than in adjacent pastures, as previously documented by Britton et al. (unpublished data, 2002). 


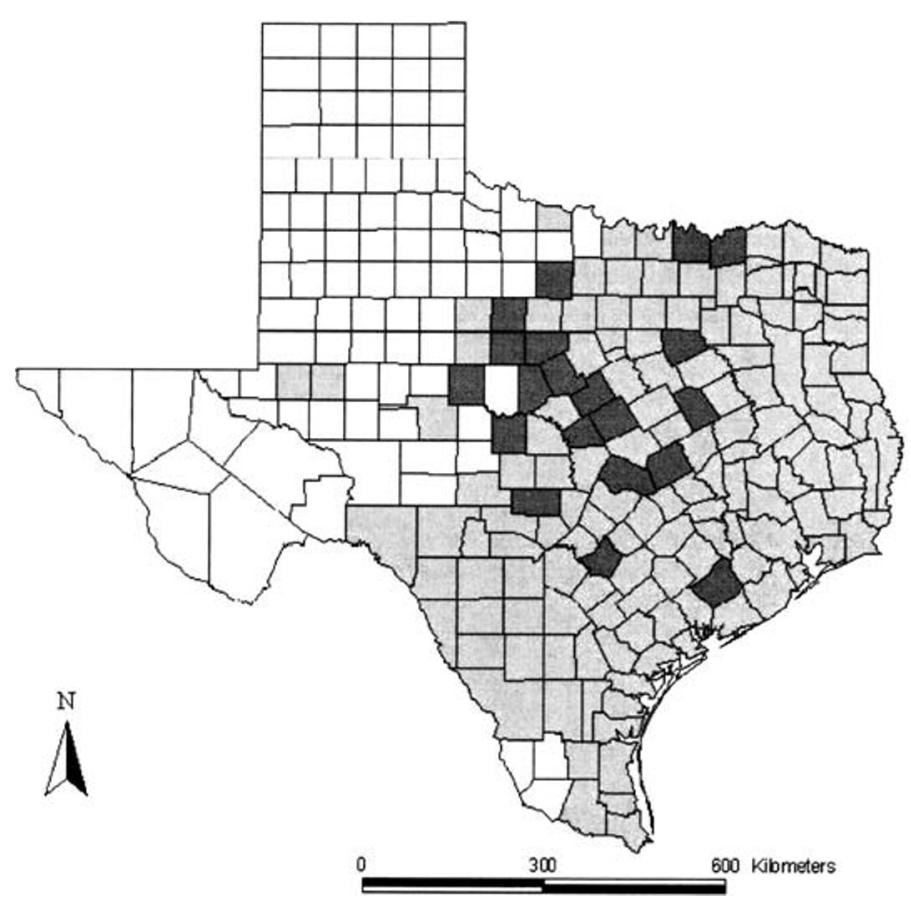

Figure 1. Texas counties infested with Solenopsis invicta (light grey). Counties in which the current study was conducted are indicated in dark grey and span the entire range in which both the ant and WW-B.Dahl grass coincide.

\section{METHODS}

RIFA and WW-B.Dahl grass are found together throughout central and north Texas. We selected 25 sites, providing a geographically variable sample group (Fig. 1). At each site, we studied two adjacent plots, one with established WW-B.Dahl and the other featuring a different grass, such as Bermuda (Cynodon dactylon [L.] Pers). Based on external investigation, fields shared soil, slope, and other major characteristics. Sites were visited March-June 2004, when air temperatures ranged between $22^{\circ}-36^{\circ} \mathrm{C}$, allowing for maximum ant foraging activity (Porter and Tschinkel 1987). Northern sites were visited later than southern ones, to reduce the differences in climatic conditions among sites. To document this, we recorded temperature at the soil surface, at a depth of $2 \mathrm{~cm}$, and at $1 \mathrm{~m}$ above the surface (Porter and Tschinkel 1987; Vogt et al. 2003). Temperatures were not significantly correlated with measured ant activity (Pearson correlations, $P>0.05$ in all cases) and, thus, are not addressed further below. We also tested whether grass height and density (measured using the Daubenmire cover scale; Bonham 1989), time of day, altitude, and estimated shading affected ant abundance in the field. As with temperature, these factors had little relationship to ant captures and are not discussed below.

We employed 2 methods to simultaneously sample ant presence in both plots at each site: standardized bait cup (Mueller et al. 1999) and mound counts (Forbes 1999; Forbes et al. 2000). Bait-cup sampling involved placing 10, 30-ml plastic cups $10 \mathrm{~m}$ apart along a $100-\mathrm{m}$ linear transect. Each cup contained $5 \mathrm{~g}$ of Tender Vittles tuna-flavored cat food (RalstonPurina, St. Louis, MO), which was moistened with water and placed on the ground for 1 hour (Jusino-Atrasino 1992; Russell et al. 2001; Morrison 2002). The first cup was placed $20 \mathrm{~m}$ from the edge of the field, and transect direction was determined by random direction sampling (Southwood 1978). Collected ants were counted and identified to species in the laboratory using a dissecting microscope. We conducted mound counts using 2, 100-m line transects per plot, placed to maximize coverage of different microhabitats within the field. Each transect was $3-\mathrm{m}$ wide and $1.5 \mathrm{~m}$ on either side of the transect line, started $20 \mathrm{~m}$ from the field edge, and was parallel to and $10 \mathrm{~m}$ apart from the bait-cup transect line. To estimate vitality, we opened the top of each counted mound and rated activity on a numerical scale based on the estimated number of workers and the presence or absence of brood (Thorvilson et al. 1992). Paired $t$ tests were used to compare ant counts between B.Dahl and non-B.Dahl fields, and we employed a $\chi^{2}$ test to compare the numerical proportions of monogyne and polygyne ants among adjacent fields.

Because the mating system can affect RIFA mound density, we used the methods of Drees and Vinson (1987) to determine whether colonies were monogynous (single queen) or polygynous (multiple queens). We used a wedge micrometer (Porter 1983) to measure head capsule width, using a mean width of $>0.789 \mathrm{~mm}$ to determine monogyny and mean $<0.74 \mathrm{~mm}$ to indicate polygyny (Greenberg et al. 1985). However, Tschinkel (1988) has pointed out that these differences may not hold in very young colonies, in which all ants tend to be small, and this might serve to obscure some differences.

\section{RESULTS}

The number of mounds in WW-B.Dahl plots ranged from 0 to 4.5 mounds per transect $\left(4.5\right.$ mounds $/ 300-\mathrm{m}^{2}$ transect $=150$ $\left.\mathrm{ha}^{-1}\right)$ and averaged 1.48 mounds per transect $(\mathrm{SD}=1.43$, $\left.49.3 \pm 47.67 \mathrm{ha}^{-1}\right)$. Mound counts in other grasses varied from 0 to 27.5 per transect $\left(0-916.7 \mathrm{ha}^{-1}\right)$, averaging $5.88 \pm$ 6.11 mounds per transect $\left(196.0 \pm 203.67 \mathrm{ha}^{-1}\right)$. The difference between the 2 was highly statistically significant (Fig. 2; $t=-3.91, \mathrm{df}=24, P=0.0006)$. Mound counts were also significantly lower in B.Dahl pastures when compared only with fields planted with Bermuda grass $(t=-2.35, \mathrm{df}=14$, $P=0.03)$ and native grasses $(t=-2.81, \mathrm{df}=6, P=0.01)$. Other grasses were not encountered frequently enough to allow for statistical comparisons. Surprisingly, the correlation between number of mounds and number of ants collected nearby was not statistically significant in any type of grass, nor were mound-vitality ratings significantly correlated with ant numbers in bait cups $(P>0.05$ in all cases).

Ant numbers per cup varied greatly in both WW-B.Dahl plots and in fields planted in other grasses (Fig. 2). However, they did not differ significantly by grass type $(t=-0.20$, $\mathrm{df}=24, P=0.84)$. Mound-vitality ratings were similarly variable (Fig. 2) and not significantly different between grass types $(t=-0.69, \mathrm{df}=24, P=0.49)$. We also examined the ant population index, obtained by multiplying the number of mounds in each category by the numerical rating (Lofgren and Williams 1982), and failed to find a significant difference between WW-B.Dahl plots and other grasses $(t=-1.85, \mathrm{df}=8$, $P=0.10)$. 


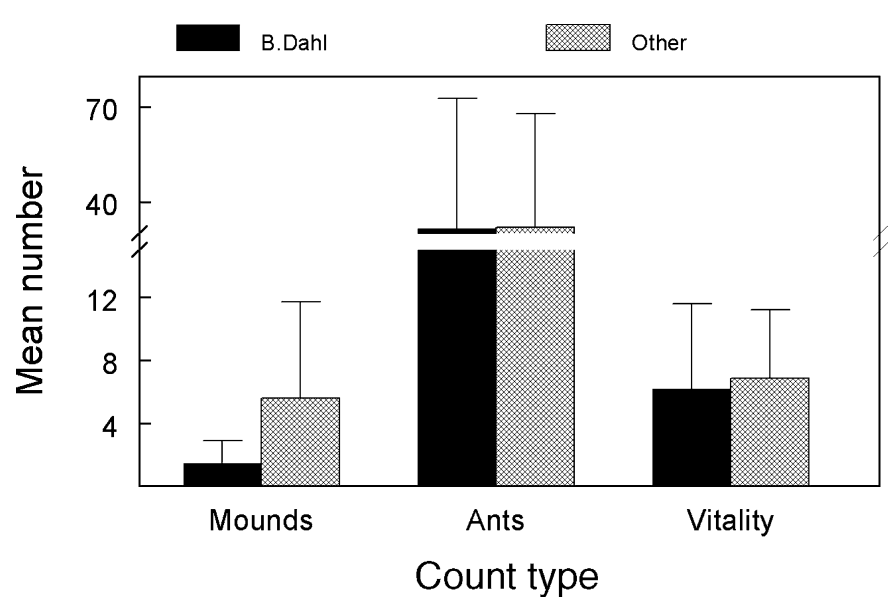

Figure 2. A comparison of pastures planted with WW-B.Dahl grass with adjacent fields planted with other grasses. Bars represent mean numbers of mounds per $300-\mathrm{m}^{2}$ transect, mean number of fire ants collected in bait cups, and mean vitality rating per mound. Error bars show 1 SD.

Some transects lacked sufficient ant numbers $(<15)$ to determine colony type, but we were able to use head-width measurements to assign ants to a reproductive mode in 23 of the 25 sites tested. Ants captured in WW-B.Dahl fields were significantly less likely to be polygynous, as indicated by head capsule width, than those collected in adjacent fields planted with other grasses (Fig. $3 ; \chi^{2}=8.04, \mathrm{df}=2, P=0.018$ ).

\section{DISCUSSION}

Landscaping materials, such as red cedar (Juniperus virginiana L.) mulch, are known to have limited efficacy in repelling RIFA (Thorvilson and Rudd 2001; Anderson et al. 2002). We found significantly fewer mounds in plots planted with B.Dahl than in adjacent fields planted with other species of grass, a considerably larger effect than previously reported. Whereas mound counts were significantly reduced in B.Dahl fields, the number of ants collected in bait cups did not differ among grass types, even though mound-vitality ratings varied little among grass types. This discrepancy has been noted by others (M. Merchant, unpublished data, 2005; H. Thorvilson, personal communication, July 2005; M. Wallace, personal communication, July 2005) and calls into question the effectiveness of sampling techniques, such as bait cups, which have traditionally been used to estimate ant populations. One possible explanation is offered by our finding that polygene mounds, which typically are more dense (reviewed in Taber 2000), are significantly more common in nearby plots than in B.Dahl fields. Our reliance on head-width measurements may have obscured some differences between colony types, as the difference is not apparent in young colonies (Tschinkel 1988). However, we do not see any reason why young colonies should be more common in one field type than another and, thus, do not consider this to be a major source of concern in the present study. If our assignment of colony type is correct, then the larger number of monogyne colonies found in B.Dahl pastures might help explain the discrepancy. This issue clearly requires further study.

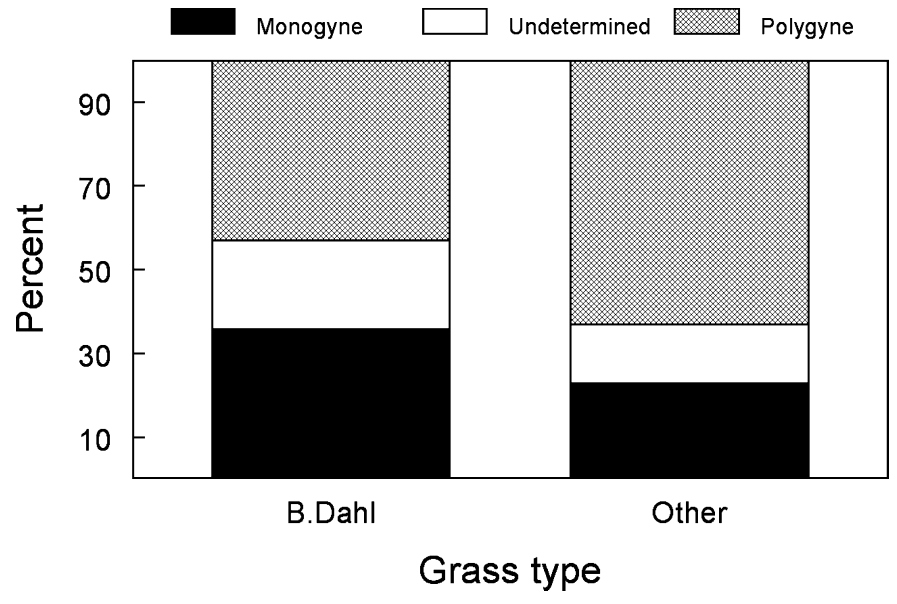

Figure 3. Proportions of ants showing various reproductive strategies, as indicated by head capsule width. The difference between ants found in WW-B.Dahl and other grasses is statistically significant.

The mechanism by which B.Dahl appears to repel RIFA is unclear. If our assignment of colony type is correct, then polygene mounds are significantly less common in B.Dahl fields. Whether this is enough to account for the 3-fold reduction in mound count that we documented, remains to be seen. Regardless of reproductive strategy, however, the question remains how this effect was achieved. Several authors have noted that some members of the grass genus Bothriochloa are less attractive than others to insects (Zalkow et al. 1980), suggesting some species "are resistant to the impacts of some insect pests" (Pinder and Kerr 1980). Thus, it is possible that B.Dahl, which has a strong smell, produces a chemical or chemicals that affect the ants directly or indirectly. We are currently working to examine this hypothesis and isolate such chemicals, if they, indeed, exist. Regardless of mechanism, the lower number of RIFA colonies found in B.Dahl grass and its attractiveness as forage offer another tool for managers interested in reducing ant damage while maintaining other activities on their land.

\section{MANAGEMENT IMPLICATIONS}

The presence of B.Dahl is associated with a reduced number of RIFA mounds in a wide range of environments. A reduction in the number of RIFAs can have multiple benefits. At the economic end, operators of hay-harvesting equipment are currently forced to raise cutting levels because of RIFA mounds to avoid equipment damage in infested fields (Taber 2000), and a reduction in mound density will lessen crop loss due to inefficient harvesting. Landowners will also benefit from decreased mound density because high RIFA-infestation levels reduce land values (Hung et al. 1977). Finally, RIFAs are known to cause high economic losses in other extractive agroindustries, such as cattle raising (e.g., Teal et al. 1999). A reduction in ant infestation can thus enhance the profitability of such operations. A reduction in RIFA presence can also have positive effects on wildlife. For example, the presence of fire ants is known to adversely impact the presence of native ants that are the preferred food of horned lizards (genus Phrynosoma; 
Donaldson et al. 1994). Similarly, Dabbert et al. (2002) showed that RIFAs negatively impact bobwhite quail. Reducing the presence of RIFAs should, thus, also help wildlife numbers to increase, an impact that we did not assess during this study.

\section{ACKNOWLEDGMENTS}

We thank the landowners who allowed us to conduct research on their land and $\mathrm{H}$. Thorvilson and B. Vinson for their helpful comments throughout the work. J. Cokendolpher helped with analyses of ants, R. Alrich helped in the field, and C. Villalobos translated the abstract into Spanish. This is publication number T-9-1070 of the College of Agriculture and Natural Resources, Texas Tech University.

\section{LITERATURE CITED}

Anderson, J. T., H. Thorvilson, and S. A. Russell. 2002. Landscape materials as repellents of red imported fire ants. Southwestern Entomologist 27: 155-163.

BonHAm, C. 1989. Measurements for terrestrial vegetation. New York, NY: John Wiley and Sons. $352 \mathrm{p}$.

Dabbert, C. B., R. B. Mitchell, J. M. Mueller, A. R. Forbes, and J. H. Treadway. 2002. Northern bobwhite and red imported fire ant interactions in the Texas coastal plains. Southwestern Entomologist Supplement 25:105-110.

DreEs, B., And S. Vinson. 1987. Are multiple queen mounds of the red imported fire ant more difficult to control than single queen mounds? Report TA22928. Available at: http://fireant.tamu.edu/research/arr/Category/Ecological/ 86-87Pg10/86-87Pg10.pdf. Accessed 31 August 2005.

Forbes, A. 1999. Effects of bobwhite habitat management on red imported fire ant populations [MS thesis]. Lubbock, TX: Texas Tech University. $39 \mathrm{p}$.

Forbes, A. R., J. M. Mueller, R. B. Mitchell, C. B. Dabbert, and D. B. Wester. 2000. Accuracy of red imported fire ant mound density estimates. Southwestern Entomologist 25:109-112.

GreEnBERG, L., D. FLetcheR, AND S. Vinson. 1985. Differences in worker size and mound distribution in monogynous and polygynous colonies of the fire ant Solenopsis invicta Buren. Journal of the Kansas Entomological Society 58:9-18.

Hung, A. C. F., M. R. BarLin, And S. B. Vinson. 1977. Identification, distribution, and biology of fire ants in Texas. Texas Agricultural Experiment Station Bulletin 1185:1-24.

Jusino-Atresino, R. 1992. Alteration of foraging patterns of native ant species in central Texas by the red imported fire ant, Solenopsis invicta, Buren [MS thesis]. Lubbock, TX: Texas Tech University. 69 p.

Lard, C., V. Salin, D. Willis, S. Robison, J. Hadley, and K. Schroeder. 2001. The statewide economic impact of red imported fire ants in Texas: a part of the
Texas fire ant initiative 1999-2001. College Station, TX: Texas A\&M University. Fire Ant Economic Research Report \#01-08.

Lofgren, C., AND D. Williams. 1982. Avermectin $B_{1}$ : a highly potent inhibitor of reproduction by queens of the red imported fire ant. Journal of Economic Entomology 75:798-803.

MoRRISON, L. 2002. Long-term impact of an arthropod-community invasion by the imported fire ant, Solenopsis invicta. Ecology 83:2337-2345.

Morrison, L., S. Porter, E. Daniels, and M. Korzukhin. 2004. Potential global range expansion of the invasive fire ant, Solenopsis invicta. Biological Invasions 6:183-191.

Mueller, J., C. Dabbert, S. Demarais, and A. Forbes. 1999. Northern bobwhite chick mortality caused by red imported fire ants. Journal of Wildlife Management 63:1291-1298.

Pinder, A. R., ANd S. K. KerR. 1980. The volatile essential oils of five Bothriochloa species. Phytochemistry 19:1871-1873.

PORTER, S. 1983. Fast, accurate method of measuring ant head widths. Annals of the Entomological Society of America 76:866-867.

Porter, S., and W. Tschinkel. 1987. Foraging in Solenopsis invicta: effects of weather and season. Environmental Entomology 16:802-808.

Russell, S., H. Thorvilson, and S. Phillips, JR. 2001. Red imported fire ant (Hymenoptera: Formicidae) populations in Texas highways rights-of-way and adjacent pastures. Environmental Entomology 30:267-273.

Southwood, T. 1978. Ecological methods. London, United Kingdom: Chapman and Hall. $492 \mathrm{p}$.

TABER, S. 2000. Fire ants. College Station, TX: Texas A\&M University Press. 308 p.

Teal, S., E. Segarra, C. Barr, and B. Drees. 1999. The cost of red imported fire ant infestation: the case of the Texas cattle industry. Texas Journal of Agriculture and Natural Resources 12:88-97.

Thorvilson, H., J. Cokendolpher, and S. Phillips, JR. 1992. Survival of the red imported fire ant (Hymenoptera: Formicidae) on the Texas High Plains. Environmental Entomology 21:964-968.

THORVILson, H., AND B. RudD. 2001. Are landscaping mulches repellent to red imported fire ants? Southwestern Entomologist 26:195-203.

TSCHINKEL, W. R. 1988. Colony growth and the ontogeny of worker polymorphism in the fire ant, Solenopsis invicta. Behavioral Ecology and Sociobiology 22:103-115.

Villalobos, C., M. Avila, G. Bezanilla, C. M. Britton, and C. Ortega-Ochoa. 2003. Old World bluestems and their forage potential for the north east of Mexico. Aldama, Tamaulipas, Mexico: Research Institution for Livestock, Agriculture, and Forestry. $12 \mathrm{p}$.

VINSON, S. B. 1997. Invasion of the red imported fire ant (Hymenoptera: Formicidae): spread, biology, and impact. American Entomologist 43:23-39.

VoGT, J. 2003. Attractiveness and effectiveness of an artificial diet fed to hybrid imported fire ants, Solenopsis invicta $\times$ Richteri (Hymenoptera: Formicidae). Florida Entomologist 86:456-459.

Zalkow, L. H., J. T. Baxter, R. J. McClure, JR., and M. M. Gordon. 1980. A phytochemical investigation of Bothriochloa intermedia. Journal of Natural Products 43:598-608. 